\title{
Tantangan Industri Kecil Sepatu Sandal Dalam Menghadapi Revolusi Industri 4.0 Untuk Meningkatkan Pendapatan Pengrajin (Studi di Desa Sukaresmi Kecamatan Tamansari Kabupaten Bogor, Jawa Barat)
}

\author{
Juliati Prihatini \\ Staf Pengajar IPDN (Institut Pemerintahan Dalam Negeri) \\ Email : julie_pri@yahoo.com
}

\begin{tabular}{ll}
\hline ARTICLE INFO & ABSTRACT \\
\hline
\end{tabular}

Keywords:

Industri Kecil, Inovasi Teknologi, Pendapatan
Industri kecil merupakan ekonomi rakyat yang memiliki peranan besar bagi masyarakat terutama tentang permasalahan sosial ekonomi seperti pemutusan hubungan kerja, kemiskinan dan sebagainya. Industri kecil dapat memberikan kontribusi terhadap devisa negara karena dapat membuka lapangan kerja, meningkatkan produk nasional, ekspor dan sebagainya. Besarnya kontribusi yang diberikan industri kecil menunjukkan pentingnya keberadaan industri kecil dan perlu adanya langkah - langkah pembinaan dan pengembangan dari pemerintah guna meningkatkan pendapatan pengrajin. Desa Sukaresmi Kecamatan Tamansari Kabupaten Bogor memiliki industri kecil sepatu sandal terbanyak yaitu 289 buah (Dinas Koperasi UKM Perindustrian dan Perdagangan, 2014). Industri kecil ini merupakan mata pencaharian utama masyarakat, dikerjakan di rumah - rumah dengan tenaga kerja rata - rata $7-8$ orang. Untuk pengembangan industri kecil di era sekarang perlu diberi dukungan peralatan/teknologi yang bermanfaat bagi pengrajin. Hal ini disebabkan penggunaan teknologi akan menentukan kuantitas dan kualitas hasil produksi, sehingga output yang dihasilkan memenuhi kriteria seperti yang diharapkan konsumen. Tujuan penelitian ini adalah untuk mengetahui dan menganalisis tentang upaya - upaya yang dilakukan oleh Dinas Koperasi UKM Perindustrian dan Perdagangan terhadap industri kecil sepatu sandal dalam menghadapi tantangan revolusi industri 4.0 untuk meningkatkan pendapatan pengrajin di Desa Sukaresmi Kecamatan Tamansari Kabupaten Bogor. Metode penelitian ini adalah kualitatif, teknik pengumpulan data lapangan dilakukan secara observasi, wawancara semi struktur dan wawancara berstruktur. Hasil penelitian menunjukkan bahwa industri kecil sepatu sandal di Desa Sukaresmi Kecamatan Tamansari dapat meningkatkan pendapatan pengrajin dan tenaga kerja walaupun tidak secara berkelanjutan. Untuk menghadapi tantangan revolusi industri 4.0 guna meningkatkan pendapatan pengrajin, Pemerintah Kabupaten Bogor (Dinas Koperasi UKM Perindag) belum memfasilitasi pemberian bantuan peralatan; pemberian pelatihan GKM dan AMT; peningkatan akses dan pangsa pasar; promosi dan inovasi dan sosialisasi Balai Latihan Kerja (BLK)., sehingga dalam memproduksi sepatu sandal masih menggunakan peralatan seadanya. Kesimpulan dari penelitian ini adalah industri kecil sepatu sandal di Desa Sukaresmi dapat menyerap tenaga kerja 2.023 orang $(95,60 \%)$; pendapatan pengrajin dan tenaga kerja tidak secara berkelanjutan dan belum adanya fasilitasi dari Dinas Koperasi UKM Perindag Kabupaten Bogor

\section{PENDAHULUAN}

Industri kecil dan menengah merupakan ekonomi rakyat yang memiliki peranan besar bagi masyarakat terutama tentang permasalahan sosial ekonomi seperti pemutusan hubungan kerja, kemiskinan dan sebagainya. Di Indonesia, peranan industri kecil (Tambunan, 2001 : 73) adalah mengurangi pengangguran, memberikan stabilisator dalam masyarakat, mengatasi ketidakmerataan, meningkatkan pertumbuhan output minimal, meningkatkan agroindustri, meningkatkan ekspor, meningkatkan pendapatan nasional dan membantu mengentaskan kemiskinan. Dengan adanya industri kecil dan menengah yang merupakan tulang punggung perekonomian masyarakat ini maka 
peranan industri kecil dan menengah sangat penting.(Vikaliana, Harsanti, Wulandari, \& Andayani, 2017)

Untuk pengembangan industri kecil di era revolusi industri 4.0 perlu diberi dukungan peralatan teknologi yang bermanfaat bagi pengrajin. Hal ini disebabkan penggunaan teknologi akan menentukan kuantitas dan kualitas hasil produksi, sehingga output yang dihasilkan memenuhi kriteria seperti yang diharapkan konsumen.

Bertolak dari hal tersebut, tantangan industri kecil dan menengah di Indonesia adalah masih banyaknya hambatan yang ditemukan yaitu salah satunya adalah masalah sosial dan kurangnya Pemerintah dalam memberikan motivasi pengembangan industri kecil. Pemerintah Pusat dan Pemerintah Daerah Kabupaten Bogor (Dinas Koperasi UKM Perindustrian dan Perdagangan) hendaknya memfasilitasi pengusaha industri kecil dalam hal manajemen, pembinaan dan pelatihan kerja, akses memperoleh modal usaha dan teknologi, sehingga hambatan - hambatan yang dihadapi pengrajin industri kecil dapat diminimalisir. (Vikaliana \& Andayani, 2018)

Desa Sukaresmi merupakan salah satu desa di Kecamatan Tamansari Kabupaten Bogor yang memiliki industri kecil sepatu sandal terbanyak yaitu 289 buah (Dinas Koperasi UKM Perindustrian dan Perdagangan Kabupaten Bogor, 2014). Industri kecil ini dikerjakan di rumah - rumah dan merupakan mata pencaharian utama masyarakat serta berkaitan dengan pendapatan.

Industri kecil sepatu sandal di Desa Sukaresmi Kecamatan Tamansari kurang tergali dengan baik potensinya, hal ini disebabkan kurangnya pembinaan para pengrajin tentang masalah manajemen organisasi oleh pemerintah. Permasalahan yang perlu disikapi adalah terbatasnya modal yang dimiliki pengrajin, penggunaan peralatan yang sederhana, ketatnya prosedur pemberian kredit (lembaga keuangan/bank) kepada pengrajin industri kecil untuk memperoleh bantuan dana investasi guna pengembangan industri kecil.

Dalam kaitannya dengan industri kecil, Pemerintah Pusat dan Pemerintah Daerah Kabupaten Bogor seyogyanya memberikan perhatian terhadap beberapa sektor yaitu sektor pendidikan dan pelatihan (terutama penggunaan peralatan/teknologi), sektor produksi, sektor manajemen, sektor pemasaran, sektor tenaga kerja dan sektor permodalan. Oleh karena itu industri kecil sepatu sandal untuk menghadapi tantangan era revolusi industri 4.0 perlu disikapi dengan pembinaan dan fasilitasi dari Pemerintah Pusat dan Pemerintah Daerah Kabupaten Bogor.

\section{Rumusan Masalah}

Rumusan masalah dalam penelitian ini adalah :

- Apa saja upaya - upaya yang dilakukan oleh Dinas Koperasi UKM Perindustrian dan Perdagangan Kabupaten Bogor terhadap industri kecil sepatu sandal dalam menghadapi tantangan revolusi industri 4.0 untuk meningkatkan pendapatan pengrajin di Desa Sukaresmi Kecamatan Tamansari Kabupaten Bogor?

\section{Tujuan Penelitian}

Tujuan penelitian ini adalah :

- Untuk mengetahui dan menganalisis upaya - upaya yang dilakukan oleh Dinas Koperasi UKM Perindustrian dan Perdagangan terhadap industri kecil sepatu sandal dalam menghadapi tantangan revolusi industri 4.0 untuk meningkatkan pendapatan pengrajin di Desa Sukaresmi Kecamatan Tamansari Kabupaten Bogor.

\section{KAJIAN TEORITIS}

\section{Industri Kecil}

Tohar, M. (2000 : 11) menyatakan bahwa industri kecil adalah badan usaha yang menjalankan proses produksi untuk menghasilkan barang dan jasa dalam skala kecil. Jika dilihat dari sifat dan bentuknya maka industri kecil bercirikan antara lain : 
1. Berbasis pada sumber daya lokal sehingga dapat memanfaatkan potensi secara maksimal dan memperkuat kemandirian.

2. Dimiliki dan dilaksanakan oleh masyarakat lokal sehingga mampu mengembangkan sumber daya manusia.

3. Menerapkan teknologi lokal (indigeneous technology) sehingga dapat dilaksanakan dan dikembangkan oleh tenaga lokal.

4. Tersebar dalam jumlah yang banyak sehingga merupakan pemerataan pembangunan yang efektif.

Kuncoro, Mudrajat (2007 : 365) menyatakan bahwa industri kecil memiliki karakteristik yang hampir seragam yaitu :

1. Tidak adanya pembagian tugas yang jelas antara bidang administrasi dan operasi. Kebanyakan industri kecil dikelola oleh perorangan yang merangkap sebagai pemilik sekaligus pengelola perusahaan serta memanfaatkan tenaga kerja dari keluarga dan kerabat dekatnya.

2. Rendahnya akses industri kecil terhadap lembaga - lembaga kredit formal, sehingga mereka cenderung menggantungkan pembiayaan usahanya dari modal sendiri atau sumber - sumber lain seperti keluarga, kerabat, pedagang perantara bahkan rentenir.

3. Sebagian besar usaha kecil ditandai dengan belum memiliki status badan hukum.

Lebih lanjut Mudrajat menyatakan bahwa masalah dasar yang dihadapi pengusaha kecil adalah :

1. Kelemahan dalam memperoleh peluang pasar dan memperbesar pangsa pasar.

2. Kelemahan dalam struktur permodalan dan keterbatasan untuk memperoleh jalur terhadap sumber sumber permodalan.

3. Kelemahan dibidang organisasi dan manajemen sumber daya manusia.

4. Keterbatasan jaringan usaha kerjasama antar pengusaha kecil (sistem informasi pemasaran).

5. Pembinaan yang telah dilakukan masih kurang terpadu dan kurangnya kepercayaan serta kepedulian masyarakat terhadap usaha kecil.

Prayitno, Hadi (1985 : 50) menyatakan terdapat beberapa alasan mengapa pembangunan industri kecil diperlukan :

1. Karena letaknya di daerah pedesaan maka tidak akan menambah migrasi ke kota atau dengan kata lain mengurangi laju urbanisasi.

2. Sifatnya yang padat tenaga kerja akan memberikan kemampuan serap lebih besar per unit yang diinvestasikan.

3. Masih dimungkinkan bagi tenaga kerja yang terserap dengan letak yang berdekatan, untuk kembali berburuh tani dalam usaha tani khususnya menjelangnya dan saat sibuk.

4. Penggunaan teknologi yang sederhana mudah dipelajari dan dilaksanakan.

\section{Inovasi Teknologi}

Inovasi adalah penciptaan produk yang lebih baik atau lebih efektif, proses, layanan, teknologi atau gagasan yang diterima oleh pasar, pemerintah dan masyarakat. Atau menurut Freeman, inovasi adalah proses yang mencakup kegiatan teknis, desain, pengembangan, manajemen dan mengakibatkan komersialisasi baru (atau yang ditingkatkan) produk, atau penggunaan pertama dari baru (atau yang ditingkatkan) dalam proses. Inovasi teknologi adalah memperkenalkan suatu teknologi yang baru, pelayanan yang baru dan cara - cara baru yang lebih bermanfaat (sandi.tkjbrondong.blogspot.com/2015/12/definisi-dan-contoh-inovasi-teknologi.

\section{Pendapatan Masyarakat/Pengrajin}

Pendapatan masyarakat/pengrajin adalah nilai barang dan jasa yang dihasilkan oleh masyarakat dalam kurun waktu tertentu (biasanya satu tahun) yang dihitung berdasarkan uang pada waktu itu (Gilarso, T., $1998: 30$ ). 


\section{METODOLOGI}

\section{Desain Penelitian}

Desain penelitian ini adalah kualitatif dengan menggunakan metode deskriptif analisis. Sugiyono (2008 : 1) menyatakan bahwa metode penelitian kualitatif adalah metode penelitian yang digunakan untuk meneliti pada kondisi obyek yang alamiah, dimana peneliti adalah sebagai instrumen kunci, teknik pengumpulan data dilakukan secara gabungan, analisis data bersifat induktif dan hasil penelitian kualitatif lebih menekankan makna daripada generalisasi.

\section{Sumber Data Penelitian}

Sumber data dalam penelitian ini diperoleh dari sumber data primer dan sumber data sekunder. Dalam penelitian ini, informan sebagai sumber data primer yang penulis wawancara berjumlah 40 orang meliputi Kepala Dinas Koperasi UKM Perindag Kabupaten Bogor, Kabid. Perindustrian Dinas Koperasi UKM Perindag, Kasi Manajemen Usaha dan Pengembangan SDM UKM Dinas Koperasi UKM Perindag, Kasi Fasilitasi Permodalan Dinas Koperasi UKM Perindag, Camat Tamansari, Kades Sukaresmi dan Pengrajin Industri Kecil Sepatu Sandal di Desa Sukaresmi.

\section{Teknik Pengumpulan Data}

Teknik pengumpulan data dalam penelitian ini dilakukan dengan cara observasi, wawancara semi struktur dan wawancara berstruktur.

\section{Teknik Analisis Data}

Teknik analisis data yang dilakukan penulis dalam penelitian ini adalah menginventarisasi jumlah industri kecil sepatu sandal di Desa Sukaresmi; mengumpulkan data yang berkaitan dengan industri kecil sepatu sandal di Desa Sukaresmi dengan cara dokumentasi yang diperoleh dari Dinas Koperasi UKM Perindag Kabupaten Bogor, Kecamatan Tamansari, Desa Sukaresmi dan Pengrajin Industri Kecil Sepatu Sandal di Desa Sukaresmi; menganalisis upaya - upaya Dinas Koperasi UKM Perindustrian dan Perdagangan terhadap industri kecil sepatu sandal dalam menghadapi tantangan revolusi industri 4.0 guna meningkatkan pendapatan pengrajin di Desa Sukaresmi Kecamatan Tamansari Kabupaten Bogor.

\section{Lokasi dan Jadwal Penelitian}

Penelitian ini dilaksanakan pada bulan Juni - Agustus 2015 di Desa Sukaresmi Kecamatan Tamansari Kabupaten Bogor Provinsi Jawa Barat.

\section{HASIL PENELITIAN DAN PEMBAHASAN}

Industri kecil sepatu sandal di Desa Sukaresmi Kecamatan Tamansari sebanyak 289 buah masih menggunakan peralatan sederhana untuk proses produksinya. Di Kabupaten Bogor sebenarnya sudah terdapat Balai Latihan Kerja (BLK) untuk industri alas kaki yaitu di Kecamatan Ciomas. Teknologi untuk proses produksi sepatu sandal/alas kaki di BLK tersebut cukup lengkap, tetapi jarak tempuh dari Kecamatan Tamansari ke Kecamatan Ciomas cukup jauh sehingga pengrajin industri kecil sepatu sandal di Desa Sukaresmi menggunakan peralatan seadanya.

Walaupun demikian, jumlah industri kecil sepatu sandal di Desa Sukaresmi sebanyak 289 buah mampu menyerap tenaga kerja sebanyak 2.023 orang (95,60 \%)(Dinas Koperasi UKM Perindag Kabupaten Bogor, 2014), dibandingkan dengan penyerapan tenaga kerja pada industri yang lain di Desa Sukaresmi. Pengrajin industri kecil sepatu sandal rata - rata memiliki tenaga kerja $7-8$ orang.

Hasil penelitian menunjukkan bahwa industri kecil sepatu sandal di Desa Sukaresmi Kecamatan Tamansari Kabupaten Bogor dapat meningkatkan pendapatan pengrajin dan tenaga kerja. Hal ini ditunjukkan pada tabel 1 dan 2 berikut. 
Tabel 1 Kondisi Permodalan dan Keuntungan Pengrajin Industri Kecil Sepatu Sandal di Desa Sukaresmi

\begin{tabular}{|c|l|l|c|c|}
\hline No & \multicolumn{1}{|c|}{ Jenis Usaha } & $\begin{array}{c}\text { Harga Jual Sepatu Sandal yang } \\
\text { telah Diproduksi (kodi/bulan } \\
\text { dalam rupiah) }\end{array}$ & $\begin{array}{c}\text { Modal yang } \\
\text { Dikeluarkan (Rp) }\end{array}$ & $\begin{array}{c}\text { Keuntungan per } \\
\text { bulan(Rp) }\end{array}$ \\
\hline 1 & $\begin{array}{l}\text { Tahun 2014: } \\
\text { Sepatu }\end{array}$ & $\begin{array}{l}\text { 260 kodi x 650.000,00 } \\
169.000 .000,00\end{array}$ & $111.079 .000,00$ & $57.921 .000,00$ \\
& Sandal & $\begin{array}{l}320 \text { kodi x } 800.000,00= \\
256.000 .000,00\end{array}$ & $200.472 .000,00$ & $55.528 .000,00$ \\
\hline 2 & $\begin{array}{l}\text { Tahun 2015: } \\
\text { Sepatu }\end{array}$ & $\begin{array}{l}260 \text { kodi } x \text { 670.000,00 } \\
174.200 .000,00\end{array}$ & $111.079 .000,00$ & $63.121 .000,00$ \\
& Sandal & $\begin{array}{l}320 \text { kodi } x 810.000,00= \\
259.200 .000,00\end{array}$ & $200.472 .000,00$ & $58.782 .000,00$ \\
\hline
\end{tabular}

Sumber : Wawancara dengan salah satu pengrajin industri kecil sepatu sandal di Desa Sukaresmi, Tahun 2015

Pendapatan yang diterima oleh pengrajin yang tertera pada tabel 1 di atas tidak setiap bulan seperti itu, hal ini tergantung pada ada tidaknya pesanan/order dari konsumen. Walaupun tidak ada pesanan dari konsumen, pengrajin tetap memproduksi sepatu sandal dengan modal sesuai kemampuan mereka yang lalu produknya dipasarkan ke Kabupaten/Kota Bogor.

Tabel 2 Pendapatan Tenaga Kerja Setelah Bekerja pada Industri Kecil Sepatu Sandal di Desa Sukaresmi

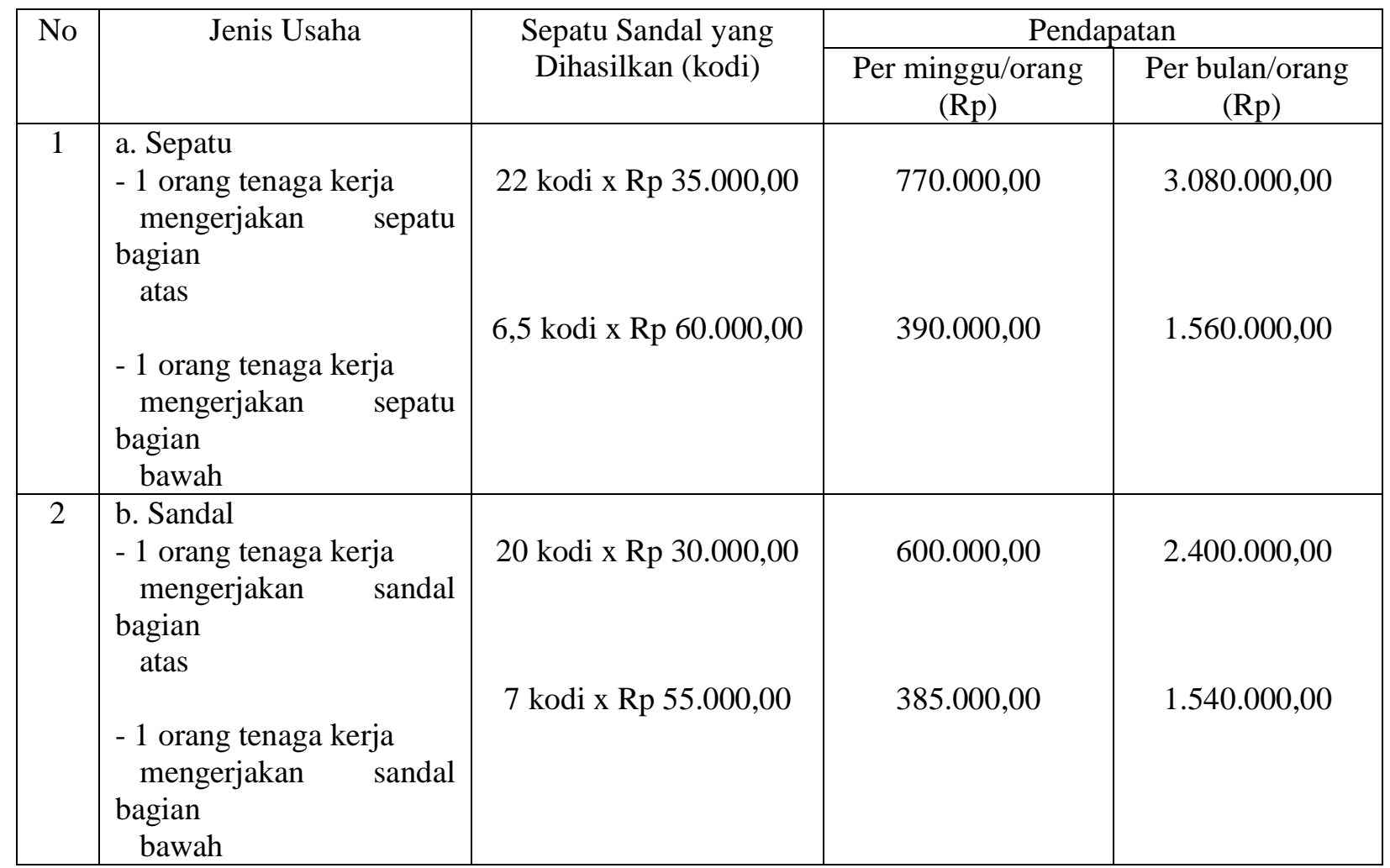

Sumber : Wawancara dengan salah satu tenaga kerja pada industri kecil sepatu sandal di Desa Sukaresmi, Tahun 2015 
Pendapatan tenaga kerja ini jauh lebih besar jika dibandingkan dengan sebelum menjadi tenaga kerja pada industri kecil yaitu sebagai buruh tani dengan pendapatan $=\mathrm{Rp} 20.000,00 / \mathrm{orang} / \mathrm{hari}$ dan kadang - kadang tidak menentu.

Upaya - upaya yang dilakukan oleh Dinas Koperasi UKM Perindustrian dan Perdagangan Kabupaten Bogor terhadap pengrajin dan tenaga kerja antara lain adalah :

\section{Pemberian Bantuan Peralatan}

Kualitas dan kuantitas hasil produksi ditentukan oleh salah satu faktor produksi yaitu peralatan/teknologi. Dengan teknologi yang diterapkan maka pengrajin akan mendapatkan hasil produksi yang seragam dan efektif.

Dinas Koperasi UKM Perindustrian dan Perdagangan Kabupaten Bogor pernah memberikan bantuan peralatan kepada pengrajin industri kecil alas kaki (sepatu sandal) di kecamatan lain selain Kecamatan Tamansari. Bantuan peralatan tersebut seperti disajikan pada tabel 3 berikut :

Tabel 3 Bantuan Peralatan dari Kementerian Perindustrian Republik Indonesia Untuk Pengrajin Industri Kecil Alas kaki (Sepatu Sandal) di Kabupaten Bogor Tahun 2014

\begin{tabular}{|c|l|l|c|c|c|c|}
\hline No & Nama Kelompok & \multicolumn{1}{|c|}{$\begin{array}{c}\text { Nama Ketua } \\
\text { Kelompok }\end{array}$} & Jenis Usaha & $\begin{array}{l}\text { Jumlah } \\
\text { Peserta } \\
\text { (orang) }\end{array}$ & Bantuan & Keterangan \\
\hline 1 & Mekarjaya I & Suherman & Alas kaki & 10 & $\begin{array}{l}\text { Pelatihan dan } \\
\text { Mesin }\end{array}$ & $\begin{array}{l}\text { Direktorat } \\
\text { IKM } \\
\text { Wilayah II } \\
\text { Ditjen IKM }\end{array}$ \\
\hline 2 & Bersama & Atang & sda & 10 & sda & sda \\
\hline 3 & Bangkit & Ma'mun & sda & 10 & sda & sda \\
\hline 4 & Sawargi & Kusnadi & sda & 10 & sda & sda \\
\hline 5 & GMC & Jajat Sudrajat & sda & 10 & sda & sda \\
\hline
\end{tabular}

\begin{tabular}{|c|c|c|c|c|c|c|}
\hline 1 & 2 & 3 & 4 & 5 & 6 & 7 \\
\hline 6 & Gumelar & Opang & sda & 10 & sda & sda \\
\hline 7 & Sauyunan & Nana Nahrowi & sda & 10 & sda & sda \\
\hline 8 & Bangkit Sayagi & Saefudin & sda & 10 & sda & sda \\
\hline 9 & Karya Mandiri & Rahmat Setiadi & sda & 4 & sda & sda \\
\hline 10 & Harapan & $\begin{array}{l}\text { Maman } \\
\text { Abdurahman }\end{array}$ & sda & 5 & sda & sda \\
\hline 11 & Elly Shoes & Ujang Oha & sda & 3 & sda & sda \\
\hline 12 & Kenanga & Eni Sukmawati & sda & 4 & sda & sda \\
\hline 13 & Berkah Lestari & Dadang Suryana & sda & 3 & sda & sda \\
\hline 14 & Cahaya Bersama & Iyan Gunawan & sda & 4 & sda & sda \\
\hline 15 & Taruna Lestari & Yanto & sda & 5 & sda & sda \\
\hline 16 & $\begin{array}{ll}\text { Usaha } & \text { Maju } \\
\text { Bersama } & \end{array}$ & Komarudin & sda & 5 & sda & sda \\
\hline 17 & Karya Maju & Junaedi & sda & 5 & sda & sda \\
\hline 18 & Jaya Abadi & M. Nawawi & sda & 5 & sda & sda \\
\hline
\end{tabular}

Sumber : Dinas Koperasi UKM Perindustrian dan Perdagangan, Tahun 2014

Bantuan mesin yang diperoleh berupa mesin semi modern yaitu masih diperlukannya tenaga kerja manusia. Walaupun demikian hasil produksi sepatu sandal yang diperoleh relatif seragam. Teknologi berupa mesin memerlukan pemikiran tentang bagaimana penggunaan alat tersebut dan apa manfaatnya. Hal ini disebabkan satu mesin dapat memiliki multifungsi, misalnya mesin tersebut dapat digunakan untuk menjahit, mengobras, memasang kancing dan sebagainya sehingga perlu adanya pemahaman dari para pengrajin industri kecil sepatu sandal. 
Untuk tahun - tahun yang akan datang Dinas Koperasi UKM Perindustrian dan Perdagangan hendaknya juga memberikan bantuan peralatan dan pelatihan kepada pengrajin industri kecil sepatu sandal di Kecamatan Tamansari khususnya Desa Sukaresmi. Hal ini karena Desa Sukaresmi memiliki jumlah pengrajin industri kecil sepatu sandal yang paling banyak dibandingkan dengan desa lain di Kecamatan Tamansari.

\section{Pemberian Pelatihan}

Sumber daya manusia dalam hal ini pengrajin industri kecil dapat dilatih melalui skill dan pemberian motivasi kepada mereka. Dinas Koperasi UKM Perindustrian dan Perdagangan Kabupaten Bogor telah berupaya memberikan keterampilan melalui pelatihan dan motivasi kepada pengrajin industri kecil sepatu sandal untuk meningkatkan kualitas produksi mereka, kecuali pengrajin industri kecil sepatu sandal di Desa Sukaresmi. Pelatihan yang diberikan antara lain :

a. Pelatihan Keterampilan

a1. GKM (Gugus Kendali Mutu) yaitu merancang proses produksi dimulai dari pemilihan bahan baku, proses produksi dan finishing. GKM tujuannya adalah untuk memperkecil hasil produk yang reject/ditolak, misalnya produk sepatu sandal yang cacat.

a2. Peningkatan Mutu

Peningkatan mutu ini dimaksudkan dalam rangka memberikan kemampuan produksi agar produk berkualitas dengan berbagai bahan baku misalnya kulit dan imitasi.

b. Pelatihan Motivasi berupa :

b1. AMT (Achievement Motivation Training)

Tujuan Pelatihan AMT :

- Meningkatkan bekal pengetahuan AMT bagi pengusaha industri kecil dan menengah

- Mampu berdaya saing dan bertanggung jawab secara pribadi dengan tidak selalu menyalahkan keadaan dan orang lain.

- Membentuk pemahaman wirausaha yang berhasil.

- Meningkatkan pengetahuan tentang budaya kerja.

- Bekal untuk bertindak sebagai seorang wirausaha sejati melalui segala sesuatu perlu perencanaan, konsep resiko, melihat dan memperhatikan dari pengalaman dengan penetapan tujuan baik jangka panjang, menengah maupun jangka panjang.

- Peningkatan perencanaan usaha serta mereview segala sesuatu yang telah dilakukan.

- meningkatkan pemahaman tentang bisnis.

Program Pelatihan AMT ini sangat bermanfaat untuk memberikan semangat dan memotivasi pengrajin industri kecil sepatu sandal dalam memajukan usahanya. Dengan diberikannya Pelatihan AMT kepada pengrajin industri kecil sepatu sandal ini maka pengrajin tersebut dapat mengelola usahanya dengan cara yang benar, disamping adanya bimbingan dari Dinas Koperasi UKM Perindustrian dan Perdagangan Kabupaten Bogor.

Pada tahun - tahun yang akan datang hendaknya pengrajin industri kecil sepatu sandal di Desa Sukaresmi Kecamatan Tamansari mendapat giliran untuk diberikan pelatihan seperti ini layaknya pengrajin industri kecil sepatu sandal di Kabupaten Bogor.

\section{Peningkatan Akses dan Pangsa Pasar}

Dalam hal akses dan pangsa pasar, sarana dan prasarana usaha yang cukup memadai dibantu oleh Dinas Koperasi UKM Perindustrian dan Perdagangan kabupaten Bogor antara lain fasilitasi untuk mendapatkan Surat Izin Usaha (SIU). Dengan dimilikinya SIU oleh pengrajin maka Dinas Koperasi UKM Perindag kabupaten Bogor memiliki data jumlah pengrajin industri kecil sepatu sandal yang ada di Kabupaten Bogor. Oleh karena itu SIU wajib dimiliki oleh masyarakat yang memiliki usaha. Sampai dengan penelitian ini dilakukan, pengrajin industri kecil sepatu sandal di Desa Sukaresmi belum ada yang memiliki SIU, sehingga mereka tidak dapat mengembangkan usahanya dengan cara meminjam modal uang ke Lembaga Keuangan yaitu Bank atau Koperasi. Hendaknya Dinas Koperasi UKM Perindag Kabupaten Bogor memfasilitasi kepada semua pengrajin industri kecil sepatu sandal se kabupaten Bogor. 


\title{
4. Melakukan Kegiatan Promosi dan Informasi
}

Untuk menawarkan produk kepada seseorang atau sekelompok orang maka perlu dilakukan kegiatan promosi. Dinas Koperasi UKM Perindag Kabupaten Bogor telah melakukan berbagai upaya promosi antara lain beberapa pengrajin industri kecil sepatu sandal diikutkan pameran di PRJ (Pekan Raya Jakarta), Pameran di Kota Banjarbaru Provinsi Kalimantan Timur dan menyediakan sarana pasar bagi para pelaku IKM dengan mendirikan galeri UKM DEKRANASDA di Kabupaten Bogor.

Pengrajin industri kecil sepatu sandal di Desa Sukaresmi Kecamatan Tamansari belum pernah ikut pameran seperti di atas, tetapi mereka sering mendapat pesanan dari konsumen seperti hasil wawancara penulis dengan salah satu pengrajin industri kecil sepatu sandal berikut. Hasil wawancara Penulis dengan Bapak Karom salah satu pengrajin industri kecil sepatu sandal di Desa Sukaresmi tanggal 11 Juni 2015 menyatakan bahwa :

\begin{abstract}
Konsumen yang memesan produk sepatu sandal ada yang datang sendiri ke tempat pengrajin industri kecil sepatu sandal. Dalam memesan produk tersebut, ada konsumen yang memberikan uang muka kepada pengrajin untuk dibuatkan sepatu sandal sesuai pesanan. Setelah pesanan sepatu sandal selesai dibuat, konsumen memberikan sisa uang yang harus dibayar. Ada juga konsumen yang secara penuh memberikan uang untuk modal pembuatan sepatu sandal sesuai pesanan, jadi pengrajin hanya menerima upah pembuatan sepatu sandal tersebut.
\end{abstract}

Ajang promosi yang dilakukan agar produk dikenali oleh orang atau sekelompok orang adalah pameran. Melalui pameran, produk yang dihasilkan secara otomatis akan bertambah jaringan pemasarannya. Untuk itu Pemerintah Daerah Kabupaten Bogor dalam hal ini Dinas koperasi UKM Perindag hendaknya memfasilitasi hal tersebut secara bergiliran. Hal ini disebabkan industri kecil sepatu sandal merupakan salah satu IKM di Kabupaten Bogor dan merupakan penggerak ekonomi daerah yang pembuatannya memerlukan keterampilan tertentu. Dengan demikian Pendapatan Asli Daerah Desa Sukaresmi meningkat dan secara otomatis pendapatan pengrajin industri kecil sepatu sandal juga meningkat.

\section{Sosialisasi Balai Latihan Kerja (BLK)}

Dinas Koperasi UKM Perindag Kabupaten Bogor memiliki Balai Latihan Kerja (BLK). Khusus untuk industri kecil sepatu sandal lokasinya di UPT Alas kaki di Kecamatan Ciomas Bogor. Dengan adanya UPT ini, diharapkan keterampilan pengrajin industri kecil sepatu sandal meningkat karena pengrajin tersebut terkait secara langsung dengan proses produksi. Apalagi jika dikaitkan dengan tingkat pendidikan pengrajin dan tenaga kerja yang mayoritas adalah lulusan SD dan SLTP.

Hasil wawancara penulis dengan Bapak Drs. H. Achmad Sofyan, MM selaku Camat Tamansari Kabupaten Bogor pada tanggal 12 Juni 2015 menyatakan bahwa :

Pemerintah Kabupaten Bogor telah menyediakan Balai Latihan Kerja di UPT Ciomas Kabupaten Bogor. Untuk pengrajin industri kecil sepatu sandal di Desa Sukaresmi belum pernah diberikan pelatihan AMT dan GKM di Balai Latihan Kerja tersebut. Tetapi karena mereka sudah bekerja cukup lama sehingga anggapannya mereka cukup terampil dalam menjalankan proses produksi.

Untuk mengembangkan usahanya, pengrajin industri kecil sepatu sandal perlu diberi sosialisasi tentang Balai Latihan Kerja. Dengan disosialisasikannya BLK sehingga pengrajin industri kecil sepatu sandal termotivasi untuk meningkatkan sumber daya manusia yang terampil dan mampu mengelola usahanya dengan terciptanya inovasi baru.

\section{KESIMPULAN DAN REKOMENDASI}

\section{Kesimpulan}

1. Industri kecil sepatu sandal sebanyak 289 buah di Desa Sukaresmi Kecamatan Tamansari Kabupaten Bogor dapat menyerap tenaga kerja sebanyak 2.023 orang $(95,60 \%)$ jauh lebih besar dibandingkan dengan industri kecil lainnya. 
2. Industri kecil sepatu sandal di Desa Sukaresmi Kecamatan Tamansari Kabupaten Bogor berperanan dalam meningkatkan pendapatan pengrajin yaitu keuntungan produk sepatu (tahun 2014) = Rp.57.921.000,00/bulan; produk sandal (tahun 2014) = Rp 55.528.000,00/bulan; produk sepatu $(2015)=\operatorname{Rp} 63.121 .000,00$ dan produk sandal $(2015)=\mathrm{Rp} 58.782 .000,00 /$ bulan.

Pendapatan tenaga kerja yang mengerjakan sepatu bagian atas = Rp 3.080.000,00/orang/bulan; mengerjakan sepatu bagian bawah $=\mathrm{Rp} 1.560 .000,00 /$ orang/bulan. Pendapatan tenaga kerja yang mengerjakan sandal bagian atas $=$ Rp 2.400.000,00/orang/bulan; mengerjakan sandal bagian bawah $=\mathrm{Rp}$ 1.540.000,00/orang/bulan. Pendapatan tenaga kerja ini jauh lebih besar jika dibandingkan dengan sebelum menjadi tenaga kerja pada industri kecil yaitu sebagai buruh tani dengan pendapatan $=$ Rp 20.000,00/orang/hari dan kadang - kadang tidak menentu .

3. Pengrajin industri kecil sepatu sandal di Desa Sukaresmi Kecamatan Tamansari belum pernah diberikan bantuan peralatan/teknologi untuk proses produksi; pelatihan GKM dan AMT; akses pangsa pasar; kegiatan promosi dan informasi serta sosialisasi BLK. Hal ini menjadi tantangan bagi pengrajin industri kecil sepatu sandal di Desa Sukaresmi untuk bersaing dengan pengrajin industri kecil sepatu sandal lainnya di Kabupaten Bogor.

\section{Rekomendasi}

- Perlunya fasilitasi oleh Dinas Koperasi UKM Perindag Kabupaten Bogor terhadap pengrajin industri kecil sepatu sandal di Desa Sukaresmi dalam hal bantuan peralatan/teknologi yang bermanfaat; pelatihan GKM dan AMT; akses pangsa pasar; kegiatan promosi dan informasi serta sosialisasi BLK secara berkelanjutan.

\section{DAFTAR PUSTAKAN}

Dinas Koperasi UKM Perinduatrian dan Perdagangan Kabupaten Bogor. 2014.

Gilarso, T., 1998. Pengantar Ilmu Ekonomi Mikro dan Makro. Yogyakarta : Kanisius.

Kuncoro, Mudrajat. 2007. Ekonomika Industri Indonesia Menuju Negara Indonesia Baru 2030. Yogyakarta : ANDI.

Prayitno, Hadi 1985. Pembangunan Ekonomi Desa. Yogyakarta: BPFE. sanditkjbrondong.blogspot.com/2015/12/definisi-dan-contoh-inovasi-teknologi

Sugiyono, 2008. Metode Penelitian Pendidikan. Pendekatan Kuantitatif, Kualitatif dan R \& D. Bandung : Alfabeta.

Tambunan, Tulus, 2001. Industrialisasi di Negara Sedang Berkembang Kasus Indonesia. Jakarta : Ghalia Indonesia.

Tohar, M., 2000. Membuka Usaha Kecil. Yogyakarta : Kanisius.

Vikaliana, R., \& Andayani, A. (2018). Social Entrepreneurship: Kewirausahaan Perempuan di Bogor melalui Pengolahan Kain Perca Limbah Konveksi menjadi Aksesoris. https://doi.org/https://doi.org/10.21067/jpm.v3i2.2864

Vikaliana, R., Harsanti, D., Wulandari, D. S., \& Andayani, A. (2017). A Cluster Model for Increasing Performance of Small and Medium-Scale Enterprises (A Case Study in Bogor, Indonesia). Springer, Singapore. https://doi.org/https://doi.org/10.1007/978-981-287-661-4_15 